\title{
Predator-enhanced diel vertical migration in a planktonic dinoflagellate
}

\author{
Stephen M. Bollens*, Joel A. Quenette, Gretchen Rollwagen-Bollens \\ School of the Environment, Washington State University, 14204 NE Salmon Creek Ave., Vancouver, \\ Washington 98686, USA
}

\begin{abstract}
Diel vertical migration (DVM) is a common and conspicuous behavior amongst planktonic organisms. In the case of dinoflagellates, both light and nutrients have been shown to regulate DVM, although the role of predators (grazers) has been understudied. Here we report the results of an experimental study using a system of 'plankton mini-towers' to examine the DVM behavior of the marine planktonic dinoflagellate Akashiwo sanguinea. A. sanguinea undertook a pronounced reverse DVM (down during the night, up during the day) in both the absence and presence of copepod predators (Acartia spp.). In the presence of copepods, however, the amplitude of the DVM was enhanced, providing the dinoflagellate with greater spatial separation from its 'normally' migrating predator. We briefly discuss the causes (cues) and ecological consequences of predator-enhanced DVM in dinoflagellates.
\end{abstract}

KEY WORDS: Dinoflagellate $\cdot$ Vertical distribution $\cdot$ Diel vertical migration $\cdot$ Nutrients $\cdot$ Light · Predator avoidance Resale or republication not permitted without written consent of the publisher

\section{INTRODUCTION}

Diel vertical migration (DVM) behavior is common and widespread among planktonic organisms in marine, estuarine, and freshwater systems, and can have profound consequences for pelagic ecosystems, e.g. by modulating the vertical flux of material and energy (Cushing 1951, Longhurst \& Harrison 1988, Mincks et al. 2000, Steinberg et al. 2000, Legendre \& Rivkin 2002, Hannides et al. 2009, Bollens et al. 2011a). DVM behavior is thought to have a variety of both proximate and ultimate causes (i.e. immediate cues and adaptive significances, respectively). For mesozooplankton such as copepods and cladocerans, it is now widely held that predator evasion often plays a critical role (Bollens \& Frost 1989a,b, Lampert 1989, Bollens et al. 1993, Hays 2003), although non-biological factors such as light, transparency, and UV radiation can also have important effects (Forward 1988, Ringelberg 2010, Williamson et al. 2011).
Dinoflagellates also often undertake DVM, although usually in a pattern that is opposite or reverse to that of most zooplankton, i.e. they reside near the surface during the day and at depth during the night (Eppley et al. 1968, Blasco 1978, Cullen \& Horrigan 1981, Ault 2000, Schofield et al. 2006, Jephson \& Carlsson 2009). A wide range of field, laboratory, and modeling studies have shown that both nutrients and light influence dinoflagellate DVM (Heaney \& Furnass 1980, Cullen \& Horrigan 1981, Kamykowski 1981, MacIntyre et al. 1997, Kamykowski et al. 1998, Erga et al. 2003, Doblin et al. 2006, Ji \& Franks 2007, Ralston et al. 2007). However, the role of predators (grazers) in triggering or enhancing DVM in dinoflagellates has largely gone unstudied.

Here we report the results of a replicated and wellcontrolled experimental study using a system of 'plankton mini-towers' that have been successfully deployed to study DVM in a range of other planktonic organisms (Speekmann et al. 2000, Lougee et al. 2002, Bochdansky \& Bollens 2004, Clay et al. 2004, 
Ignoffo et al. 2005, Bochdansky et al. 2010, Breckenridge \& Bollens 2010). Again, the role of both nutrients and light in regulating DVM in dinoflagellates cannot be denied (see references above), but here we test for the additional effect of predators (copepods) on enhancing the DVM behavior of the dinoflagellate Akashiwo sanguinea.

\section{MATERIALS AND METHODS}

\section{Culturing and collection of organisms}

A clone of the dinoflagellate Akashiwo sanguinea (strain no. SPMC 140) was obtained from Shannon Point Marine Center, Anacortes, Washington, USA, and maintained in a growth chamber at Washington State University, Vancouver, Washington. The growth chamber was set to $19^{\circ} \mathrm{C}$ and a $12: 12 \mathrm{~h}$ light:dark cycle using $400 \mathrm{~W}$ high pressure sodium (HPS) lamps, $400 \mathrm{~W}$ metal halide lamps, and incandescent bulbs. Cells were cultured using sterile techniques under an ultraviolet hood in $10 \mathrm{~d}$ cycles with f/2 media (-Si) and 31 ppt artificial seawater (ASW: autoclaved Milli-Q water and Instant Ocean ${ }^{\circledR}$ sea salt).

Wild copepods were collected at high tide from Yaquina Bay, Oregon, USA (24 May 2010) and the lower Columbia River estuary in Astoria, Oregon (20 September 2010) with vertical tows of a $73 \mu \mathrm{m}$, $0.5 \mathrm{~m}$ diameter ring net. Back in the laboratory, adult female copepods of the genus Acartia were sorted from the net zooplankton and acclimated for $1 \mathrm{~d}$ to experimental temperature and salinity conditions $\left(19^{\circ} \mathrm{C}, 31 \mathrm{ppt}\right)$.

\section{Experimental design and setup}

Two separate $24 \mathrm{~h}$ experiments (25 to 26 May 2010 and 21 to 22 September 2010) were performed using a set of 2 columnar tanks as described by Bochdansky \& Bollens (2004), where the control tank contained only dinoflagellates and the treatment tank contained dinoflagellates plus copepods. Experiments tested for the effects of light (diel cycle) and copepod predators (presence/absence) on the vertical distribution of Akashiwo sanguinea. This set of $2 \mathrm{~m}$ tall $(5 \mathrm{~cm}$ deep $\times 8 \mathrm{~cm}$ wide) tanks allowed for high-resolution sampling of vertical distribution of dinoflagellates using an external fluorometer, and of copepods using an automated, continuously recording video microscope. Three vertical fluorescence profiles, consisting of point collections at $10 \mathrm{~cm}$ intervals, were taken manually at midnight and midday with a Wet Labs Handheld DFLB fluorometer, and from these, a single average vertical fluorescence profile was calculated. A panning video microscope system, consisting of an infrared camera and diode mounted on a vertically traveling cradle, connected to a VCR, was used to determine $\mathrm{cm}$-scale vertical distributions of copepods every hour.

Suspended $20 \mathrm{~cm}$ above each tank were $400 \mathrm{~W}$ HPS lamps on a 12:12 h light:dark cycle. Light intensity was controlled using neutral density screens, and diffusers were placed between the HPS lamps and the tanks to mimic light quality in an aquatic environment. Light intensity was set within the ranges for Akashiwo sanguinea described by Matsubara et al. (2007); mean \pm SE surface intensity was $116.7 \pm 15.53 \mu \mathrm{mol} \mathrm{m}{ }^{-2} \mathrm{~s}^{-1}$ ( $\mathrm{n}=4$ ) and mean bottom intensity was $4.7 \pm$ $0.29 \mu \mathrm{mol} \mathrm{m}{ }^{-2} \mathrm{~s}^{-1}(\mathrm{n}=4)$. The HPS lamps, video microscopes, and VCRs were controlled through a set of programmable switches linked to a desktop computer running an automation program. Nutrients $\left(\mathrm{PO}_{4}=2 \mu \mathrm{M}, \mathrm{NO}_{3}=53 \mu \mathrm{M}\right)$ were homogenously distributed and were similar to concentrations found in Monterey Bay, California, USA (Ryan et al. 2010).

Acartia spp. are known omnivores that are capable of feeding on dinoflagellates (Rollwagen Bollens \& Penry 2003, Gifford et al. 2007). Our preliminary feeding experiments showed that Acartia readily fed on Akashiwo sanguinea and produced fecal pellets as a result, consistent with observations of other calanoid copepods (Kang \& Poulet 2000, Murray \& Marcus 2002). Expected dinoflagellate growth and copepod grazing during the experiments were estimated from Matsubara et al. (2007) and Kiørboe et al. (1985), respectively, and then prey (dinoflagellate) and copepod abundances were chosen so as to minimize the impact of grazing during the experiments (e.g. a $\sim 5 \%$ reduction of dinoflagellates), while still maintaining natural predator densities of $\sim 10$ copepods $\mathrm{l}^{-1}$.

Cultured dinoflagellates at densities of $\sim 2.15 \times$ $10^{6}$ cells were gently mixed into the nutrient-rich ASW and then, with the aid of a funnel, gently placed into the treatment and control tanks until nearly full ( $180 \mathrm{~cm}$ depth). The experiments began $2 \mathrm{~h}$ later $(21: 00 \mathrm{~h})$, when adult female copepods (64 in Expt 1, 94 in Expt 2) were added with a small volume $(<50 \mathrm{ml})$ of ASW to the surface of each treatment tank. Midnight sampling of dinoflagellates and cope- 


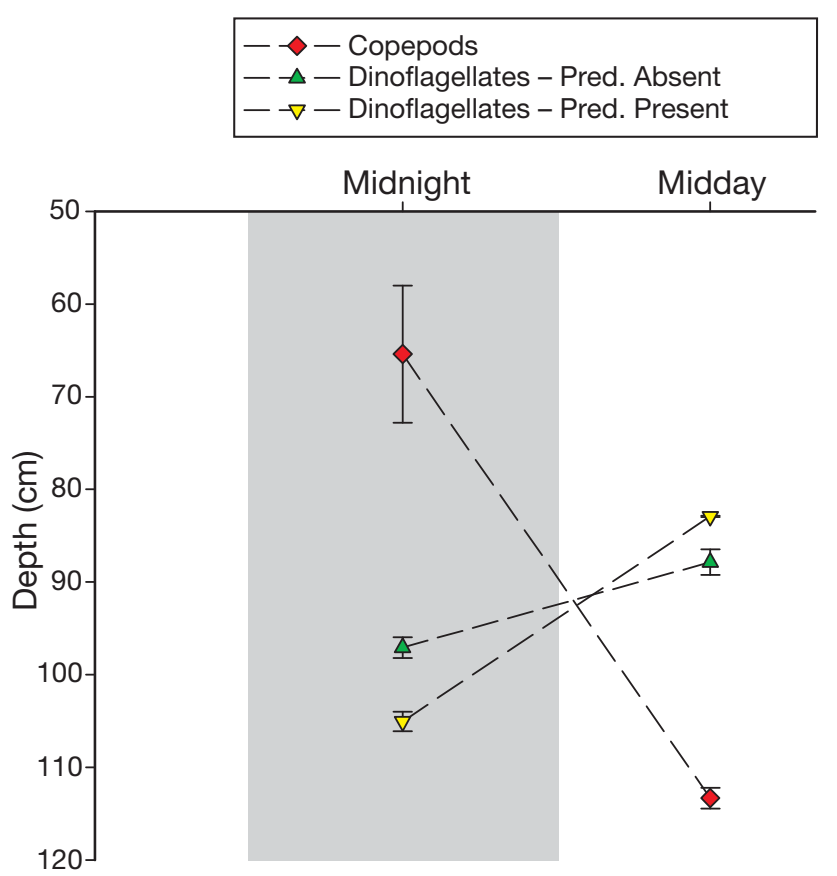

Fig. 1. Akashiwo sanguinea and Acartia spp. Diel vertical migration (DVM) of the dinoflagellate $A$. sanguinea and the copepods Acartia spp. Mean ( $\pm 1 \mathrm{SE})$ weighted mean depth during midnight and midday of copepods (red diamonds), dinoflagellates in the absence of predators (green triangles), and dinoflagellates in the presence of predators (yellow triangles). The copepods undertook 'normal' DVM and the dinoflagellates 'reverse' DVM, with the latter being enhanced (i.e. of greater magnitude) in the presence of predators

pods occurred about $5 \mathrm{~h}$ later $(02: 00 \mathrm{~h})$, and midday sampling $12 \mathrm{~h}$ after that (14:00 h). A final water column total fluorescence reading was collected $24 \mathrm{~h}$ after the initiation of each experiment $(21: 00 \mathrm{~h}$ on Day 2), to allow for calculation of total grazing losses over $24 \mathrm{~h}$.

Subsequent taxonomic identification of these copepods indicated that the vast majority were Acartia (Acartiura) spp., but a few (5\%) were Acartia tonsa. The subgenus Acartiura consists of a group of 3 species of copepods that cannot be reliably distinguished, and thus identification is typically left at the subgenus level (Bradford 1976, Bollens et al. 2011b). Both A. tonsa and A. (Acartiura) spp. have similar patterns of 'normal' DVM (Schallek 1942, Lance 1962, Stearns \& Forward 1984, Bollens et al. 1992, Kouassi et al. 2001), that is, up during the night and down during the day, and were therefore considered suitable for our experiments.

\section{Statistical analyses}

Weighted mean depths (WMDs) of copepods and dinoflagellates in each tank at midday and midnight of each experiment were calculated from video counts and water column fluorescence profiles, respectively, using the following equation (Bollens et al. 1993, Rollwagen-Bollens et al. 2006):

$$
\mathrm{WMD}=\frac{\sum\left(A_{i} \cdot Z_{i}\right)}{\sum\left(A_{i}\right)}
$$

where $i$ is each depth sampled, $A$ is the fluorescence or copepod abundance value, and $Z$ is the depth. The WMDs of dinoflagellates at midday and midnight (light effect), and in the presence and absence of copepods (predator effect), were combined from the two $24 \mathrm{~h}$ experiments, and were subsequently analyzed using 2-way analyses of variance (ANOVAs; Type III sum of squares and $\alpha=0.05$ ).

\section{RESULTS AND DISCUSSION}

The copepods in our experimental tanks undertook 'normal' DVM (up at night, down during the day) in response to a diel light cycle (Fig. 1). In contrast, the dinoflagellate Akashiwo sanguinea undertook 'reverse' DVM (down during the night, and up during the day; Fig. 1, Table 1). Dinoflagellate DVM occurred both in the absence and the presence of copepod predators, but the amplitude of the migration was greater (i.e. enhanced) in the presence of the copepods (Fig. 1, Table 1, as evidenced by the significant Light Condition $\times$ Copepods term). The ANOVA indicated no significant copepod effect alone (Table 1) because the direction of the dinoflagellate response to copepods varied depending on the presence or absence of light; dinoflagellates moved higher during the day and lower during the night, in a pattern that was reverse or opposite that of the normally migrating copepods. That is, the pres-

Table 1. Akashiwo sanguinea. Summary of results of 2-way ANOVA of A. sanguinea weighted mean depths. Significant p-values $(<0.05)$ are shown in bold

\begin{tabular}{|lcrrrrr|}
\hline Source & df & Seq. SS & Adj. SS & Adj. MS & $F$ & $\mathrm{p}$ \\
\hline Light condition & 1 & 490.67 & 490.67 & 490.67 & 233.23 & $\mathbf{0 . 0 0 0}$ \\
Copepods & 1 & 4.65 & 4.65 & 4.65 & 2.21 & 0.211 \\
Light condition $\times$ Copepods & 1 & 83.60 & 83.60 & 83.60 & 39.74 & $\mathbf{0 . 0 0 3}$ \\
Error & 4 & 8.42 & 8.42 & 2.10 & & \\
Total & 7 & 587.34 & & & & \\
$\mathrm{~S}=1.45046, \mathrm{R}^{2}=98.57 \%, \mathrm{R}^{2}$ (adj.) $=97.49 \%$ & & & \\
\hline
\end{tabular}


ence of copepod predators had the effect of enhancing or strengthening the reverse DVM of the dinoflagellates, over and above the effect of light alone. This resulted in the dinoflagellates experiencing greater spatial separation from their predators during both day and night. Although we cannot know the exact amount by which dinoflagellate mortality is reduced by this predator-evasion behavior, it has been shown for zooplankton that only a very small reduction in predation mortality is required to offset the energetic costs of diel vertical migration (e.g. Frost 1988, Ohman 1990).

The role of both nutrients and light in modulating DVM in dinoflagellates has been the focus of many previous field, experimental, and modeling studies. That light attracts some dinoflagellates to the surface during the day, and that the presence of higher nutrients at depth can induce some dinoflagellates to descend to depth during the night (e.g. below the nutricline), has been well established (see references in the 'Introduction'). What is new about our study is that it implicates predator (grazer) evasion as an additional factor influencing DVM in dinoflagellates.

Quenette (2010) performed similar experiments as those reported here, but with one important difference: most copepod predators were cultured rather than collected from the wild. Quenette (2010) found a very strong effect of light on the vertical distribution of Akashiwo sanguinea, but an inconsistent effect of copepod predators. Indeed, the results of Quenette (2010) led us to suspect that wild copepods might behave (i.e. swim and migrate) more naturally than cultured copepods, and that the dinoflagellates might therefore be more likely to respond to wild predators. The results reported herein bear this out; in the presence of wild, normally migrating copepod predators, dinoflagellates enhanced their reverse DVM behavior (Fig. 1, Table 1).

One obvious question that arises is whether depthspecific grazing might, in and of itself, have caused changes in the vertical distribution of the dinoflagellates, i.e. by disproportionately removing cells at one depth and thereby giving the false appearance that the population of dinoflagellates moved to a different depth, farther away from the copepods. Although we could not measure depth-specific grazing losses in our plankton towers, we were able to measure water column total losses due to grazing. Grazing impact over the course of the experiments, estimated using reduction in water column total fluorescence over $24 \mathrm{~h}$, was estimated to be $8.4 \%$. This level of grazing can be applied to various vertical dis- tribution patterns to test for the possible effects on WMD. Whereas we observed an $8 \mathrm{~cm}$ change in the WMD of the dinoflagellates in the first $5 \mathrm{~h}$ due to the copepod treatments, the effect of grazing losses on WMD would be far less than this, ranging from 0 (if grazing occurred at all depths in proportion to prey abundance) to a theoretical maximum of $2.9 \mathrm{~cm}$ (if grazing losses were concentrated entirely within a $10 \mathrm{~cm}$ stratum at one end of the dinoflagellate distribution and all remaining dinoflagellates occurred within the $10 \mathrm{~cm}$ stratum at the opposite end of the distribution). In all cases, the effect of grazing losses on WMD (0 to $2.9 \mathrm{~cm}$ ) are far less than the observed effect of copepods on dinoflagellate WMD $(8 \mathrm{~cm})$. In short, the low levels of grazing that occurred during our experiments could not have caused the observed changes in dinoflagellate distribution through cell removal alone. Rather, dinoflagellates must have sensed the presence of their predators and actively moved away from them, i.e. they migrated to shallower depths during the day and greater depths during the night (Fig. 1) so as to evade their predators.

This in turns raises the question of how Akashiwo sanguinea might sense the presence of copepods. Chemoreception and mechanoreception, individually or in combination, are both possibilities. Dinoflagellates have been shown to use chemoreception to detect prey (Buskey 1997) and predators (Burkholder et al. 1995, Cancellieri et al. 2001) and to use mechanoreception to detect potential predators (White 1979, Anderson et al. 1988, von Dassow et al. 2005). In crustacean zooplankton, there is now a rich body of work on chemoreception of predator-released kairomones (see reviews by Lass \& Spaak 2003 and Williamson et al. 2011), and to a lesser degree, of mechanoreception of predator cues (e.g. Bollens et al. 1994, Woodson et al. 2007). The question of how A. sanguinea sense their copepod predators, however, remains open.

This newly reported behavioral response in dinoflagellates, viz. predator-enhanced reverse DVM, could have important ecological consequences at the individual (physiological), population (growth and mortality), community (predator-prey), and ecosystem (flux) levels. Indeed, DVM behavior in dinoflagellates, when coupled with that of their predators and other higher trophic levels, could result in a 'cascade of migrations' throughout the food web, with important consequences for pelagic biogeochemical cycling (Bollens et al. 2011a). In any event, both the causes (cues) and ecological consequences of predator-enhanced DVM in dinoflagellates warrant further investigation. 
Acknowledgements. We thank A. Bochdansky and B. Frost for helpful advice and suggestions on experimental design and implementation, S. Strom for providing an inoculum of Akashiwo sanguinea, and B. Tissot for guidance on statistical analyses. This work was partially supported by ONR grant N000140610200 to S.M.B. and G.R.B.

\section{LITERATURE CITED}

Anderson DM, Nosenchuck DM, Reynolds GT, Walton AJ (1988) Mechanical stimulation of bioluminescence in the dinoflagellate Gonyaulax polyedra Stein. J Exp Mar Biol Ecol 122:277-288

Ault TR (2000) Vertical migration by the marine dinoflagellate Prorocentrum triestinum maximises photosynthetic yield. Oecologia 125:466-475

$>$ Blasco D (1978) Observations on the diel migration of marine dinoflagellates off the Baja California coast. Mar Biol 46:41-47

> Bochdansky AB, Bollens SM (2004) Relevant scales in zooplankton ecology: distribution, feeding and reproduction of the copepod Acartia hudsonica in response to thin layers of the diatom Skeletonema costatum. Limnol Oceanogr 49:625-636

> Bochdansky AB, Bollens SM, Rollwagen-Bollens GC, Gibson $\mathrm{AH}$ (2010) Effect of the heterotrophic dinoflagellate Oxyrrhis marina and the copepod Acartia tonsa on vertical carbon flux in and around thin layers of the phytoflagellate Isochrysis galbana. Mar Ecol Prog Ser 402:179-196

Bollens SM, Frost BW (1989a) Predator-induced diel vertical migration in a planktonic copepod. J Plankton Res 11: 1047-1065

Bollens SM, Frost BW (1989b) Zooplanktivorous fish and variable diel vertical migration in the marine planktonic copepod Calanus pacificus. Limnol Oceanogr 34: 1072-1083

> Bollens SM, Frost BW, Thoreson DT, Watts SD (1992) Diel vertical migration in zooplankton: field evidence in support of the predator avoidance hypothesis. Hydrobiologia 234:33-39

> Bollens SM, Osgood K, Frost BW, Watts SD (1993) Vertical distributions and susceptibilities to vertebrate predation of the marine copepods Metridia lucens and Calanus pacificus. Limnol Oceanogr 38:1827-1837

> Bollens SM, Frost BW, Cordell JR (1994) Chemical, mechanical, and visual cues in the vertical migration behavior of the marine planktonic copepod Acartia hudsonica. J Plankton Res 16:555-564

> Bollens SM, Rollwagen-Bollens GC, Quenette J, Bochdansky AB (2011a) Cascading migrations and implications for vertical fluxes in pelagic ecosystems. J Plankton Res 33:349-355

Bollens SM, Breckenridge JK, Vanden Hooff RC, Cordell JR (2011b) Mesozooplankton of the lower San Francisco Estuary: spatio-temporal patterns, ENSO effects, and the prevalence of non-indigenous species. J Plankton Res 33: 1358-1377

Bradford JM (1976) Partial revision of the Acartia subgenus Acartiura (Copepoda: Calanoida: Acartiidae). NZ J Mar Freshw Res 10:159-202

Breckenridge JK, Bollens SM (2010) Biological thin layer formation: interactions between the larval decapod, Neotrypaea californiensis, haloclines and light. J Plankton Res 32:1097-1102
Burkholder JM, Glasgow HB Jr, Hobbs CW (1995) Fish kills linked to a toxic ambush-predator dinoflagellate: distribution and environmental conditions. Mar Ecol Prog Ser 124:43-61

> Buskey EJ (1997) Behavioral components of feeding selectivity of the heterotrophic dinoflagellate Protoperidinium pellucidum. Mar Ecol Prog Ser 153:77-89

> Cancellieri PJ, Burkholder JM, Deamer-Melia NJ, Glasgow HB (2001) Chemosensory attraction of zoospores of the estuarine dinoflagellates, Pfiesteria piscicida and $P$. shumwayae, to finfish mucus and excreta. J Exp Mar Biol Ecol 264:29-45

Clay TW, Bollens SM, Bochdansky AM, Ignoffo TR (2004) The effects of thin layers on the vertical distribution of larval Pacific herring, Clupea pallasi. J Exp Mar Biol Ecol 305:171-189

> Cullen JJ, Horrigan SG (1981) Effects of nitrate on the diurnal vertical migration, carbon to nitrogen ratio, and the photosynthetic capacity of the dinoflagellate Gymnodinium splendens. Mar Biol 62:81-89

Cushing DH (1951) The vertical migration of planktonic organisms. Biol Rev Camb Philos Soc 26:158-192

> Doblin MA, Thompson PA, Revill AT, Butler ECV, Blackburn SI, Hallegraeff GM (2006) Vertical migration of the toxic dinoflagellate Gymnodinium catenatum under different concentrations of nutrients and humic substances in culture. Harmful Algae 5:665-677

> Eppley RW, Holm-Harisen O, Strickland JDH (1968) Some observations of the vertical migration of marine dinoflagellates. J Phycol 4:333-340

- Erga SR, Dybwad M, Frette Ø, Lotsberg JK, Aursland K (2003) New aspects of migratory behavior of phytoplankton in stratified waters: effects of halocline strength and light on Tetraselmis sp. (Prasinophyceae) in an artificial water column. Limnol Oceanogr 48:1202-1213

Forward RB (1988) Diel vertical migration: zooplankton photobiology and behaviour. Oceanogr Mar Biol Annu Rev 26:361-393

Frost BW (1988) Variability and possible adaptive significance of diel vertical migration in Calanus pacificus, a planktonic marine copepod. Bull Mar Sci 43: 675-694

Gifford SM, Rollwagen-Bollens G, Bollens SM (2007) Mesozooplankton omnivory in the upper San Francisco Estuary. Mar Ecol Prog Ser 348:33-46

Hannides CCS, Landry MR, Benitez-Nelson CR, Styles RM, Montoya JP, Karl DM (2009) Export stoichiometry of migrant-mediated flux of phosphorus in the North Pacific Subtropical Gyre. Deep-Sea Res I 56:73-88

> Hays GC (2003) A review of the adaptive significance and ecosystem consequences of zooplankton diel vertical migrations. Hydrobiologia 503:163-170

> Heaney SI, Furnass TI (1980) Laboratory models of diel vertical migration in the dinoflagellate Ceratium hirundinella. Freshw Biol 10:163-170

> Ignoffo TR, Bollens SM, Bochdansky AB (2005) The effect of thin layers on the vertical distribution of the rotifer Brachionus plicatilis. J Exp Mar Biol Ecol 316:167-181

Jephson T, Carlsson P (2009) Species- and stratificationdependent diel vertical migration behaviour of three dinoflagellate species in a laboratory study. J Plankton Res 31:1353-1362

Ji RB, Franks PJS (2007) Vertical migration of dinoflagellates: model analysis of strategies, growth, and vertical distribution patterns. Mar Ecol Prog Ser 344:49-61 
Kamykowski D (1981) Laboratory experiments on the diurnal vertical migration of marine dinoflagellates through temperature gradients. Mar Biol 62:57-64

Kamykowski D, Milligan EJ, Reed RE (1998) Relationships between geotaxis/phototaxis and diel vertical migration in autotrophic dinoflagellates. J Plankton Res 20: 1781-1796

Kang HK, Poulet SA (2000) Reproductive success in Calanus helgolandicus as a function of diet and egg cannibalism. Mar Ecol Prog Ser 201:241-250

Kiørboe T, Møhlenberg F, Hamburger K (1985) Bioenergetics of the planktonic copepod Acartia tonsa: relation between feeding, egg production and respiration, and composition of specific dynamic action. Mar Ecol Prog Ser 26:85-97

Kouassi E, Pagano M, Saint-Jean L, Arfi R, Bouvy M (2001) Vertical migrations and feeding rhythms of Acartia clausi and Pseudodiaptomus hessei (Copepoda: Calanoida) in a tropical lagoon (Ebrié, Côte d'Ivoire). Estuar Coast Shelf Sci 52:715-728

Lampert W (1989) The adaptive significance of diel vertical migration of zooplankton. Funct Ecol 3:21-27

- Lance J (1962) Effects of water of reduced salinity on the vertical migration of zooplankton. J Mar Biol Assoc UK 42:131-154

Lass S, Spaak P (2003) Chemically induced anti-predator defences in plankton: a review. Hydrobiologia 491:221-239

> Legendre L, Rivkin RB (2002) Fluxes of carbon in the upper ocean: regulation by food-web control nodes. Mar Ecol Prog Ser 242:95-109

Longhurst AR, Harrison WG (1988) Vertical nitrogen flux from the oceanic photic zone by diel migrant zooplankton and nekton. Deep-Sea Res 35:881-889

Lougee LA, Bollens SM, Avent SR (2002) The effects of haloclines on the vertical distribution and migration of zooplankton. J Exp Mar Biol Ecol 278:111-134

MacIntyre JG, Cullen JJ, Cembella AD (1997) Vertical migration, nutrition and toxicity in the dinoflagellate Alexandrium tamarense. Mar Ecol Prog Ser 148:201-216

Matsubara T, Nagasoe S, Yamasaki Y, Shikata T, Shimasaki Y, Oshima Y, Honjo T (2007) Effects of temperature, salinity, and irradiance on the growth of the dinoflagellate Akashiwo sanguinea. J Exp Mar Biol Ecol 342: 226-230

Mincks SL, Bollens SM, Madin LP and others (2000) Distribution, abundance, and feeding ecology of decapods in the Arabian Sea, with implications for vertical flux. Deep-Sea Res II 47:1475-1516

Murray MM, Marcus NH (2002) Survival and diapause egg production of the copepod Centropages hamatus raised on dinoflagellate diets. J Exp Mar Biol Ecol 270:39-56

Ohman MD (1990) The demographic benefits of diel vertical migration by zooplankton. Ecol Monogr 60:257-281

Quenette JA (2010) Thin layer formation and vertical migration behavior of the dinoflagellate Akashiwo sanguinea

Editorial responsibility: Graham Savidge, Portaferry, UK
Hirasaka in response to light, nutrients and predators. MS thesis. Washington State University, Vancouver, WA Ralston DK, McGillicuddy DJ, Townsend DW (2007) Asynchronous vertical migration and bimodal distribution of motile phytoplankton. J Plankton Res 29:803-821

Ringelberg J (2010) Diel vertical migration in lakes and oceans: causal explanations and adaptive significances. Springer, Dordrecht

Rollwagen-Bollens GC, Penry DL (2003) Feeding dynamics of Acartia spp. copepods in a large, temperate estuary (San Francisco Bay, CA). Mar Ecol Prog Ser 257:139-158

Rollwagen-Bollens GC, Bollens SM, Penry DL (2006) Vertical distribution of micro- and nanoplankton in the San Francisco Estuary in relation to hydrography and predators. Aquat Microb Ecol 44:143-163

Ryan JP, McManus MA, Sullivan JM (2010) Interacting physical, chemical and biological forcing of phytoplankton thin-layer variability in Monterey Bay, California. Cont Shelf Res 30:7-16

> Schallek W (1942) The vertical migration of the copepod Acartia tonsa under controlled illumination. Biol Bull (Woods Hole) 82:112-126

Schofield O, Kerfoot J, Mahoney K, Moline M, Oliver M, Lohrenz S, Kirkpatrick G (2006) Vertical migration of the toxic dinoflagellate Karenia brevis and the impact on ocean optical properties. J Geophys Res 111:C06009. doi: 10.1029/2005JC003115

Speekmann CL, Bollens SM, Avent S (2000) The effect of ultraviolet radiation on the vertical distribution and mortality of estuarine zooplankton. J Plankton Res 22: 2325-2350

> Stearns DE, Forward RB (1984) Photosensitivity of the calanoid copepod Acartia tonsa. Mar Biol 82:85-89

Steinberg DK, Carlson CA, Bates NR, Goldthwaite SA, Madin LP, Michaels AF (2000) Zooplankton vertical migration and the active transport of dissolved organic and inorganic carbon in the Sargasso Sea. Deep-Sea Res I 47:137-158

von Dassow P, Bearon RN, Latz MI (2005) Bioluminescent response of the dinoflagellate Lingulodinium polyedrum to developing flow: tuning of sensitivity and the role of desensitization in controlling a defensive behavior of a planktonic cell. Limnol Oceanogr 50:607-619

White HH (1979) Effects of dinoflagellate bioluminescence on the ingestion rates of herbivorous zooplankton. J Exp Mar Biol Ecol 36:217-224

Williamson CE, Fischer JM, Bollens SM, Overholt EP, Breckenridge JK (2011) Towards a more comprehensive theory of zooplankton diel vertical migration: integrating ultraviolet radiation and water transparency into the biotic paradigm. Limnol Oceanogr 56:1603-1623

Woodson CB, Webster DR, Weissberg MJ, Yen J (2007) The prevalence and implications of copepod behavioral responses to oceanographic gradients and biological patchiness. Integr Comp Biol 47:831-846

Submitted: July 26, 2011; Accepted: October 25, 2011

Proofs received from author(s): February 7, 2012 